\title{
14. GEOTHERMAL MEASUREMENTS ON LEG 22 OF THE D/V GLOMAR CHALLENGER
}

\author{
John G. Sclater, Department of Earth and Planetary Sciences, \\ Massachusetts Institute of Technology, Cambridge, Massachusetts \\ and \\ Albert J. Erickson, Geology and Geophysics Department, \\ Woods Hole Oceanographic Institution, Woods Hole, Massachusetts
}

\section{INTRODUCTION}

Downhole temperature measurements at the deep sea drilling sites present an excellent opportunity to get reliable heat flow values in the deep oceans (Figure 1). The measurements are more reliable than shallower conventional heat flow measurements (Langseth, 1965) because the depth of the temperature measurements reduces local environmental effects such as recent temperature changes in the bottom water and the refraction of the lines of flux due to the localized topography. Downhole temperature observations with a logging cable were reported for Leg 5 by Burns (1970) and for Leg 8 by von Herzen et al. (1971). Downhole temperature measurements with a remote vehicle were first successfully accomplished on Leg 19 (Erickson, 1973) and further successful measurements were reported for Leg 21 (von Herzen, in preparation).

On Leg 22, we obtained nine downhole temperature observations at four different sites out of thirteen attempts. Two of these sites yielded reliable downhole in situ sediment temperatures. Heat flow values were computed using thermal conductivity data measured aboard ship in sediments recovered from between the temperature measurements. This report discusses the technique and results of the downhole temperature measurements, thermal conductivity values, and finishes with a short discussion of the geophysical implications of the reliable measurements.

\section{MECHANICAL OPERATION OF THE DOWNHOLE INSTRUMENT}

The principal elements of the downhole temperature system as used on Legs 19 and 21 have been described by Erickson (in preparation). One of the goals of the heat flow experiment has been to obtain reliable temperature data without interfering with the routine coring program. In order to obtain a core after the in situ sediment temperature measurement, it is necessary to use a latching device to hold the temperature probe immobile as the weight of the drill string pushes the probe into undrilled sediment. The latch must then release the recorder up inside the inner core barrel after enough time has elapsed for a reliable temperature measurement to be obtained.

For temperature measurements made prior to Leg 22, the mechanical latch that secures the instrument to the bottom of the core barrel had been damaged by the impact of the core barrel hitting bottom. The operators on Leg 21 thought the latch released prematurely when the core barrel hit the water level inside the drill pipe, thus allowing the water and entrapped air pressure to drive the instrument to the top of the core barrel. Some damage to the top of the instrument case was noted.

To facilitate the heat flow test, some new handling procedures as follows were initiated on Leg 22:

1) The drill string was filled with water up to the level of the drilling platform prior to dropping the core barrel with the instrument. The core barrel was secured in the drill string at the surface by two set screws in a short section of drill pipe (called the saver sub), and the drill string was filled with water from the rig pump. When the pipe was full, the set screws were loosened and the core barrel released.

2) To prevent damage to the top of the instrument case, a spring-type shock absorber was installed on the top of the instrument case and is now an integral part of the heat flow instrument.

3) To prevent the mechanical latch from being damaged when the core barrel hits bottom, the latch was protected in a recessed seat in the cutting edge of the core barrel.

In addition to the mechanical latch, a new method of releasing the instrument was tried, utilizing a prototype break-away latch. The latch is basically an aluminum cylinder secured by set screws to the shaft of the instrument probe. Two or more half-inch diameter brittle plastic rods protrude at right angles to the cylinder axis and are also held in place on the probe with set screws. After pumping the drill pipe full of water, the core barrel is dropped and the saver sub removed; the pipe is then joined and the bit lowered to the bottom of the previously drilled hole. The momentum of the free falling core barrel will bury the instrument probe in the sediment and shear the plastic rods. The drill bit is left on the bottom for 10 minutes until the probe approaches thermal equilibrium.

The break-away latch worked both times it was used, and this indicates that this method of releasing the instrument can be used in soft sediments. Only two plastic rods were used to latch the instrument on these two runs. It is thought that as the sediment gets firmer, more plastic rods should be used to insure against premature unlatching of the instrument. After sufficient time has elapsed with the probe in the bottom, the bit is raised off the bottom and the pump started to assure that the core barrel has seated and is latched into the drill collar. An 8 meter core is then taken with the instrument being retrieved on top of the core.

Another method of lowering the instrument, especially useful in firm sediments or where the instrument is very delicate, is to secure the instrument to the base of the core 


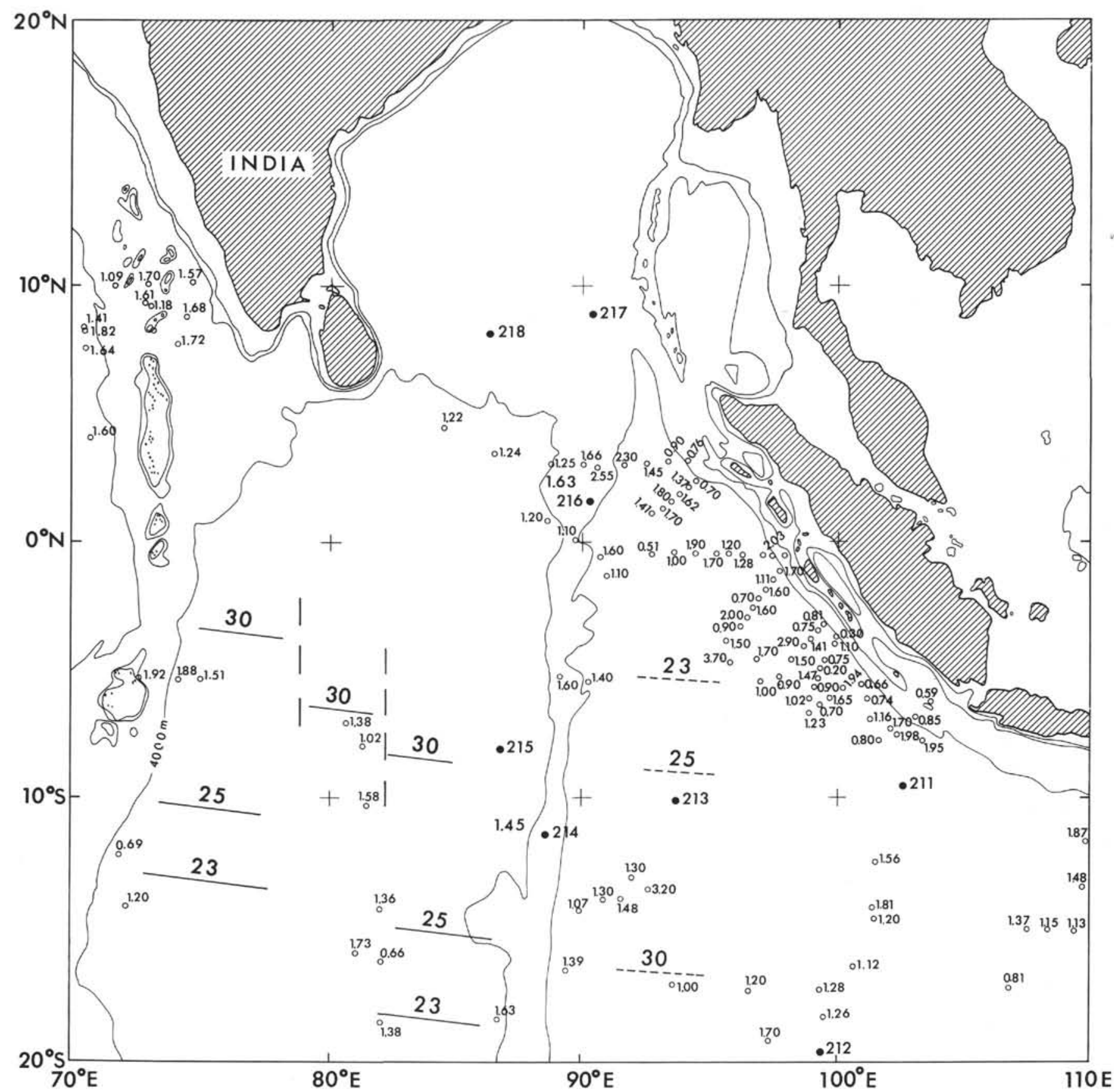

Figure 1. Heat flow values, identifiable magnetic lineation numbers, and DSDP drill sites superimposed on a topographic chart of the northwest Indian Ocean. The 4000, 1000, and 500 meter contours are shown. Data from Vacquier and Taylor (1966), Lee and Uyeda (1965), and Langseth (personal communication).

barrel and lower both on the sandline. With the bit off bottom, the core barrel is gently latched into the drill string. Then the bit is slowly lowered onto the bottom, with the weight of the bottom hole assembly pushing the probe into the sediment. This method requires a little extra time and no core is recovered with the instrument. This system was the most successful one used on Leg 22. Two excellent temperature measurements were recorded on two attempts.

\section{TEMPERATURE DATA}

Hole 213A

This was a test hole run for heat flow purposes only. After successful completion of Site 213, the drill string was retrieved to the mud line and a second hole was occupied using the original beacon. The hole was washed down to 37.5 meters and a simulated run was made without 
electronics to test newly developed techniques for loading and releasing the core barrel and for filling the drill pipe with seawater. Two temperature measurements, at 113.5 and 132.5 meters below bottom, respectively, were then tried. (Figures 2a and 2b). Although the instrument showed no damage on either lowering, the mechanical latching device was broken on the second attempt. The two successful downhole temperatures were considerably lower than expected. The sediment was very soft and a bumper sub could not be closed. It is likely that a mixed layer of water and sediment was present at the bottom of the hole, thus both measurements are considered to have been significantly disturbed by drilling fluid and have not been listed in Table 1.

\section{Site 214}

At this site, five downhole temperature measurements were attempted. Excellent data was obtained on runs 214-1 and 214-4. Usable data was obtained on 214-2. However, on runs $214-3$ and $214-5$, the recorder drive motor stopped just after penetration due to a faulty set screw in the gears. Usable data may possibly be retrieved from 214-3. All five lowerings gave roughly the same minimum water temperature (Figures 3a, b, c, and d). A brief description of each lowering follows:

Run 214-1-The latch springs sheared on this lowering. The probe appeared slightly bent. The downhole instrument was recovered with the probe fully immersed in sediment.

Run 214-2-The latches were bent and torn. The probe and pressure case were undamaged and the downhole instrument was recovered with the probe fully immersed in sediment.

Run 214-3-The latches were bent but not destroyed. The probe was undamaged and was fully immersed in sediment on recovery.

Run 214-4-The latch pins were sheared. The probe and pressure case were undamaged and the probe was fully immersed in sediment.

Run 214-5-The latches worked and were recovered undamaged. The probe and core barrel were also undamaged and the probe was fully immersed in sediment.

The actual temperature gradients on detailed analysis are disappointing because they show poor equilibrium curves. Measurements 214-3 and 214-4 are disturbed 3 to 4 minutes after penetration and 214-6 almost immediately after impact with the bottom. It is suggested that the mechanical latch may not have worked effectively on any of the lowerings. The best estimate equilibrium temperatures (presented in Table 1) show a nearly linear increase of temperature with depth.

\section{Site 216}

Four temperature measurements were attempted at this site. Though a new break-away latching system was tried, the results were disappointing (Figures $4 \mathrm{a}$ and b). The following is a brief description of the four runs:

Run 216-1-The break-away latch worked successfully. The $45 \mathrm{~cm}$ extender was buried about $25 \mathrm{~cm}$ into the sediment. The new thermistor tip showed slight flattening from impact with the old style flapper valve just above the drill bit. No data were obtained because of a blown fuse in the D.H.I.

Run 216-2-The break-away latch was again successful, however the sediment was very firm and the probe penetrated less than $10 \mathrm{~cm}$. The latch body had slid down the probe to the vicinity of the thermistor due to improper tightening of the set screws securing it to the probe.

Run 216-3-This run used the conventional mechanical latch and method of lowering. The probe was buried about $10 \mathrm{~cm}$. The release latch was about $20 \mathrm{~cm}$ above the thermistor and one latch leaf spring was slightly bent. The sediment was very firm.

Run 216-4-Same as 216-3; the probe did not penetrate and the latch release was still in its original position. Both latch leaf springs had bent when the probe encountered very hard, dry chalk. Due to an error, the D.H.I. penetrated the sediment with the drill string rotating.

Estimated subbottom depths and temperatures for the bottom water are presented in Table 1. Temperature measurement $216-4$ is unreliable as the thermistor hardly penetrated the sediment. Measurement 216-3 is also probably unreliable as the probe only penetrated $10 \mathrm{~cm}$ into the hard chalk sediment and was probably significantly disturbed by the drilling fluid.

\section{Site 217}

Two downhole temperature measurements were attempted in this hole to check the heat flow equipment for possible use on Leg 23 in the Red Sea. Owing to the sensitivity of the mechanical portions of the recorder to sudden shock, it was decided to run the heat flow equipment on the sand line. For this purpose, a core barrel was modified by drilling a hole across the bottom of the barrel some $60 \mathrm{~cm}$ above the core catcher. The D.H.I. was seated in the core barrel from the bottom and pushed up solidly against a pin inserted through the holes. The core barrel was then lowered to the bottom of the hole with the sand line. After latch-in, the drill bit was lowered 2 meters into the sediment until one bumper sub was closed. The pin prevented the D.H.I. from riding up inside the core barrel and permitted the probe to be forced into the sediment. Once the measurement was completed, the core barrel was retrieved. Although no core was taken, only 45 minutes was required for a measurement at a depth of 3000 meters.

Two successful temperature measurements at 97 and 135 meters depth below sea bottom were obtained (Table 1 and Figures $5 \mathrm{a}$ and $\mathrm{b}$ ). Both downhole values and the bottom water temperature fell close to a straight line. The equipment worked well and both temperatures appeared to be approaching constant values within $\pm 0.1^{\circ}$ on pull out.

\section{THERMAL CONDUCTIVITY MEASUREMENTS}

Tables 3 through 6 provide a summary of the thermal conductivity data collected as part of the Deep Sea Drilling Project. Table 2 gives parameters used for environmental corrections. The thermal conductivity data were obtained using the needle probe technique described by von Herzen and Maxwell (1959). The data has been reduced by digitizing the strip chart recordings of temperature versus time made aboard the D/V Glomar Challenger. The pairs of time-temperature data were then fitted by least-squares 

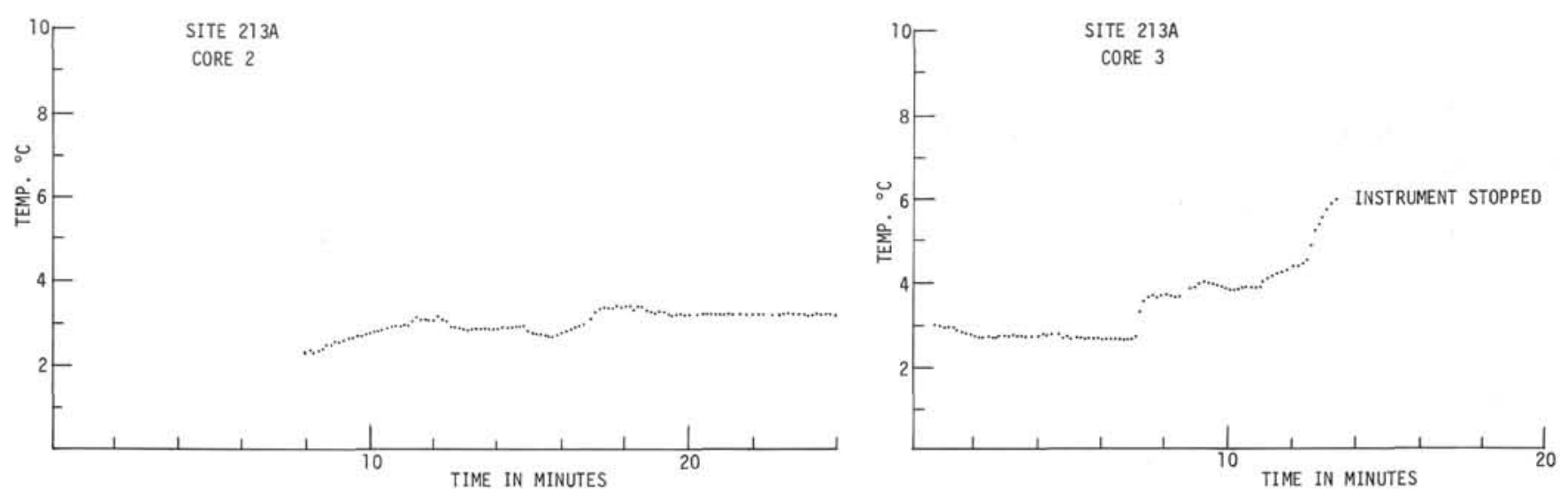

Figure 2. ( $a, b)$ Temperature data from two runs at Site 213.

TABLE

Geothermal Data, Leg 22

\begin{tabular}{|c|c|c|c|c|c|c|c|c|}
\hline \multirow[b]{2}{*}{ Site/Run } & \multirow{2}{*}{$\begin{array}{l}\text { Depth } \\
\text { (m) }\end{array}$} & \multirow{2}{*}{$\begin{array}{l}\text { Temp. } \\
\left({ }^{\circ} \mathrm{C}\right)\end{array}$} & \multirow{2}{*}{$\begin{array}{c}\text { Gradient } \\
\left({ }^{\circ} \mathrm{C} / 100 \mathrm{~m}\right)\end{array}$} & \multicolumn{3}{|c|}{$K\left(\mathrm{Mcal} / \mathrm{Cm} \mathrm{Sec}{ }^{\circ} \mathrm{C}\right)$} & \multirow{2}{*}{$\frac{I}{\left(\mathrm{Mcal} / \mathrm{Cm} \mathrm{Sec}{ }^{\circ} \mathrm{C}\right)}$} & \multirow[b]{2}{*}{ Remarks } \\
\hline & & & & No. & Mean & Std. Dev. & & \\
\hline 214 & 0 & $3.5 \pm 0.1$ & $5.02 \pm 0.15$ & 27 & $2.39^{\mathrm{a}}$ & & 1.20 & \\
\hline $214-1$ & 133.0 & $10.17 \pm 0.1$ & $5.44 \pm 1.03$ & 4 & 2.59 & 0.08 & $1.41 \pm 0.27$ & $\begin{array}{l}\text { Excellent temperature } \\
\text { measurement }\end{array}$ \\
\hline $214-2$ & 162.0 & $11.75 \pm 0.2$ & $4.89 \pm 0.67$ & 11 & 3.03 & 0.28 & $1.48 \pm 0.25$ & $\begin{array}{l}\text { Fair temperature } \\
\text { measurement }\end{array}$ \\
\hline $214-4$ & 228.5 & $15.00 \pm 0.25$ & & & & & $\begin{array}{l}1.45^{\mathrm{b}} \\
\text { (Mean Value) }\end{array}$ & $\begin{array}{l}\text { Fair temperature } \\
\text { measurement }\end{array}$ \\
\hline 216 & 0 & $2.80 \pm 0.1$ & $2.76 \pm 0.19$ & 12 & 2.70 & 0.21 & $0.75 \pm 0.08$ & \\
\hline $216-3$ & 215.0 & $8.74 \pm 0.30$ & & & & & & $\begin{array}{l}\text { Unreliable temperature } \\
\text { measurement due to } \\
\text { poor penetration of } \\
\text { sediment }\end{array}$ \\
\hline 217 & 0 & $2.00 \pm 0.1$ & $7.90 \pm 0.2$ & 17 & 2.30 & 0.16 & $1.81 \pm 0.13$ & \\
\hline $217-1$ & 97.0 & $9.66 \pm 0.1$ & $6,61 \pm 0.5$ & 2 & 2.47 & 0.22 & $1.63 \pm 0.19^{b}$ & $\begin{array}{l}\text { Excellent temperature } \\
\text { measurement }\end{array}$ \\
\hline $217-2$ & 135.0 & $12.17 \pm 0.1$ & & & & & & $\begin{array}{l}\text { Excellent temperature } \\
\text { measurement }\end{array}$ \\
\hline
\end{tabular}

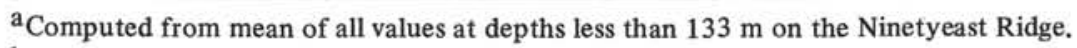

$\mathrm{b}_{\text {Final heat flow value for the site. }}$

criteria to a curve of the form $T=A+B t+C \ln t$, where $T$ and $t$ are temperature and time, respectively, and $A, B$, and $C$ are coefficients determined using a nonlinear regression program. Reduction of the data in this manner allows the removal of temperature changes due to the difference in ambient temperature between the sediment and the ship's core laboratory.

The thermal conductivity value $K$ measured in the laboratory was then corrected for pressure and temperature conditions below the sea floor using Equation 1, which is based upon correction factors presented by Ratcliffe (1960).

$$
K_{\mathrm{corr}}=K\left[1+\frac{w+\rho H}{182900}+\frac{T_{w}+H\left(d_{T} / d_{Z}\right)-T_{\text {lab }}}{400}\right]
$$

where $K_{\text {corr }}$ is the thermal conductivity corrected for temperature and pressure and 

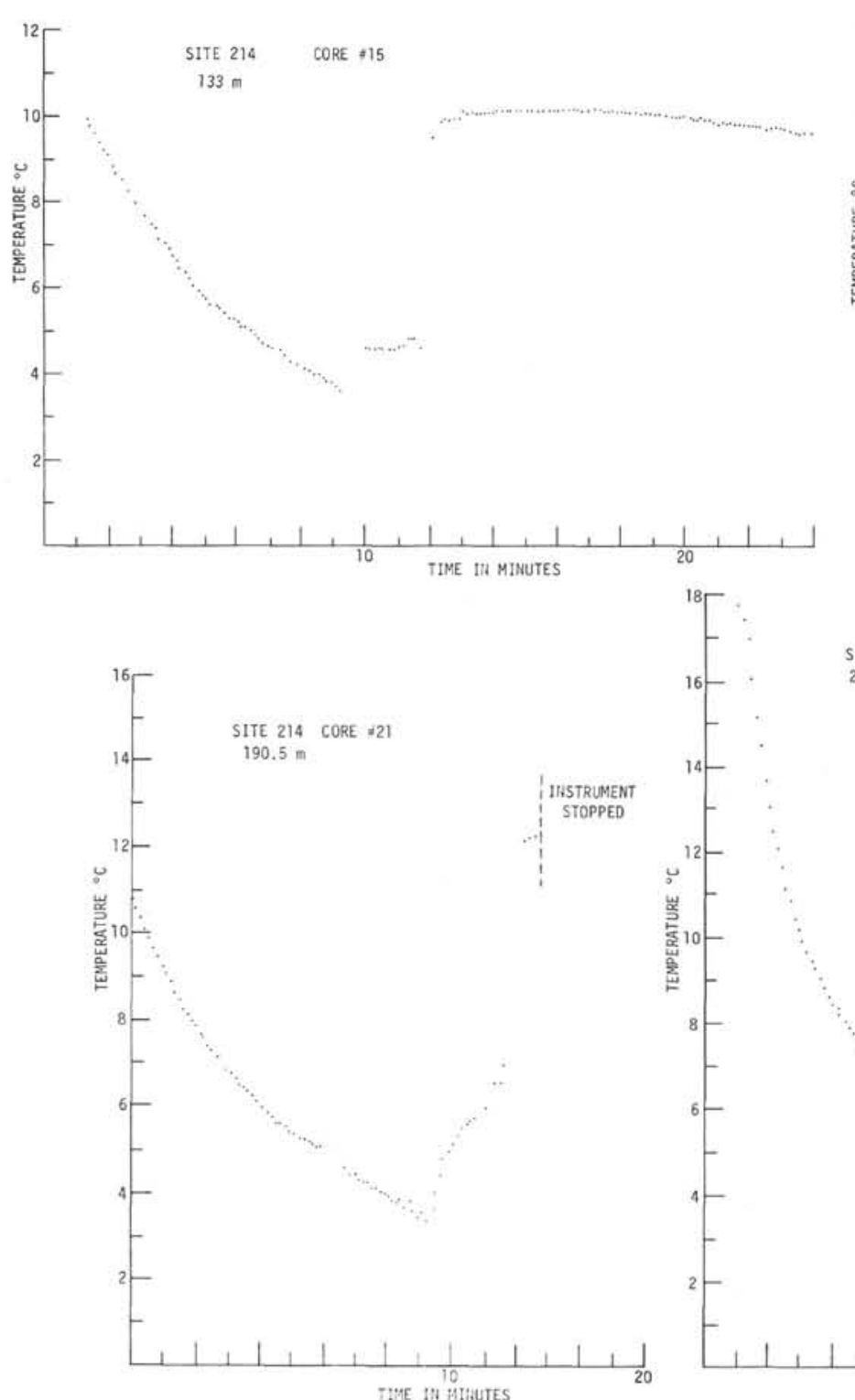

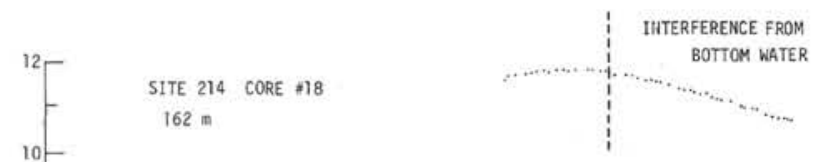

SITE $214 \quad$ CORE $\$ 25$ $228.5 \mathrm{~m}$
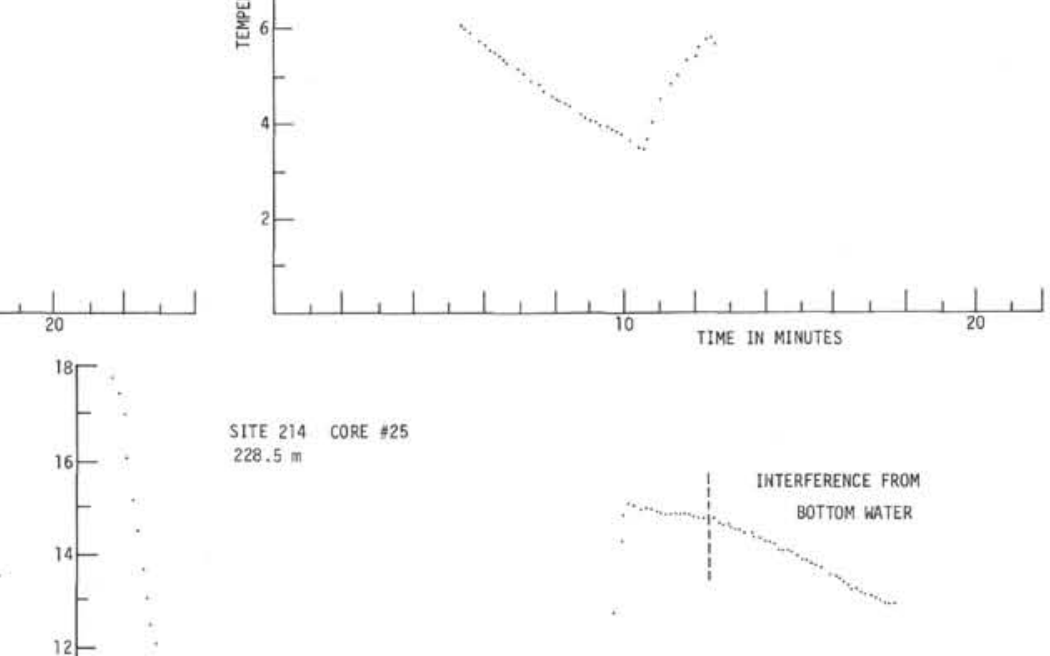

Figure 3. (a, b, c, and d) Temperature data from four runs at Site 214.

$$
\begin{aligned}
w & =\text { water depth }(\mathrm{m}) \\
\rho & =\text { mean sediment density }\left(\mathrm{gr} / \mathrm{cm}^{3}\right) \\
H & =\text { drill hole depth }(\mathrm{m}) \\
T_{w} & =\text { bottom water temperature }\left({ }^{\circ} \mathrm{C}\right) \\
d_{T} / d_{Z} & =\text { mean geothermal gradient }\left({ }^{\circ} \mathrm{C} / \mathrm{m}\right) \\
T_{\text {lab }}= & \text { laboratory ambient sediment } t \text { temperature } \\
& \left({ }^{\circ} \mathrm{C}\right)
\end{aligned}
$$

The values of these parameters used for each site for reduction of this data are presented in Table 2 . Whenever possible, these parameters have been determined using downhole temperature data $\left(T_{w}, d_{T} / d_{Z}\right)$, physical property data $(\rho)$, and bathymetric data $(W)$ for each site. Where one or more of the parameters was not determined, it was necessary to estimate these values using any other available data-specifically hydrographic data for bottom water temperature, regional heat flow values for the geothermal gradient, etc. Generally, the environmental corrections are only a few percent and the uncertainty in these parameters is negligible for most purposes.

\section{DISCUSSION OF RESULTS}

Three of the sites, 214, 216, and 217, yielded good temperature data and conductivity data (Figures 6, 7, and $8)$. However, on the single good temperature measurement at Site 216, the thermistor probe penetrated less than 10 $\mathrm{cm}$ into the undrilled sediment. The sediment temperature measured at this site is therefore not considered reliable and is not discussed further. At Site 214, which is midway down the Ninetyeast Ridge, estimates of the interval heat flow between temperature measurements have been computed. Conductivities for the upper 100 meters were taken from Site 217, which was drilled farther to the north on the Ninetyeast Ridge. The equilibrium temperatures are not very reliable (Figures $2 a, b, c$, and $d$ ); however, the 


\section{J. G. SCLATER, A. J. ERICKSON}
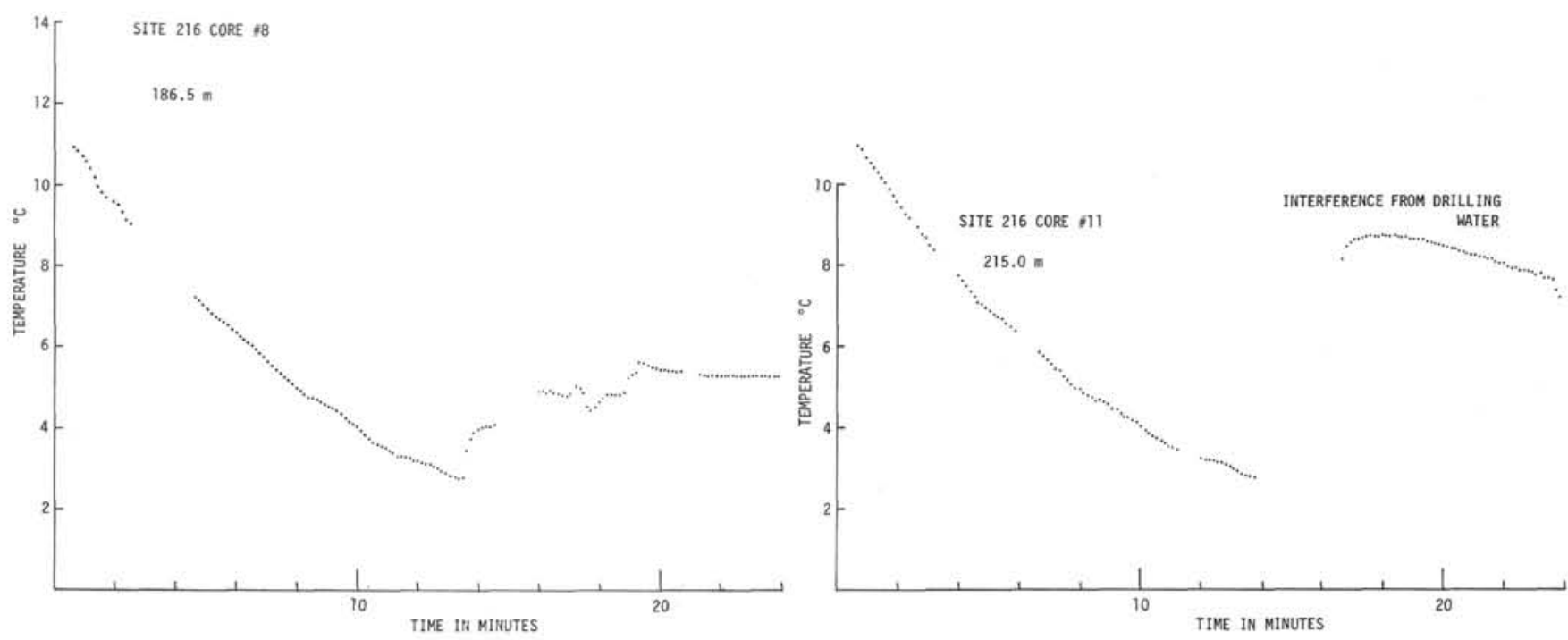

Figure 4. (a, b) Temperature data from two runs at Site 216.
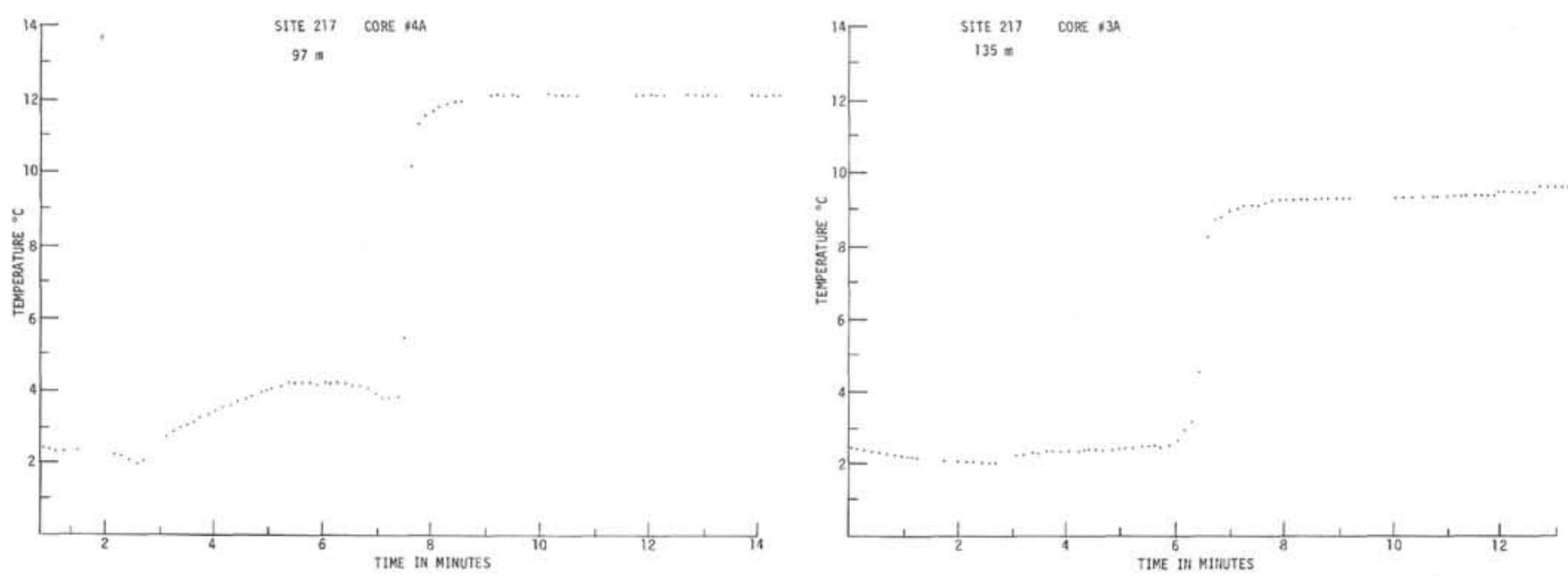

Figure 5. (a, b) Temperature data from two runs at Site 217.

TABLE 2

Site Parameters Used for Environmental Corrections

\begin{tabular}{ccccc}
\hline Site & $\begin{array}{c}\text { Water } \\
\text { Depth } \\
(\mathrm{m})\end{array}$ & $\begin{array}{c}\text { Water } \\
\text { Temp. } \\
\left({ }^{\circ} \mathrm{C}\right)\end{array}$ & $\begin{array}{c}\text { Geothermal } \\
\text { Gradient } \\
\left({ }^{\circ} \mathrm{C} / \mathrm{m}\right)\end{array}$ & $\begin{array}{c}\text { Sediment } \\
\text { Density } \\
\left(\mathrm{gr} / \mathrm{cm}^{3}\right)\end{array}$ \\
\hline 213 & 5611 & 1.68 & $0.0600^{\mathrm{a}}$ & $2.00^{\mathrm{a}}$ \\
214 & 1665 & 3.63 & 0.0503 & $2.00^{\mathrm{a}}$ \\
216 & 2247 & 2.80 & 0.0274 & $2.00^{\mathrm{a}}$ \\
217 & 3020 & 2.00 & 0.0753 & $2.00^{\mathrm{a}}$ \\
\hline
\end{tabular}

${ }^{\mathrm{a}}$ Assumed values.

good agreement between the interval heat flow values is strong evidence that the mean of the two lower intervals of $1.45 \mu \mathrm{cal} / \mathrm{cm}^{2} \mathrm{sec}$ is a reliable value. The quality of the temperature data from Site 217 is excellent. On this station, where the D.H.I. was rigidly attached to the core barrel and lowered on the sand line, excellent data were obtained. The temperature data appear to indicate a decrease in gradient with depth. However, this decrease is

not strikingly reflected in the interval heat flow values due to the observed downward increase in thermal conductivity. The heat flow computed from the lower two temperature measurements of $1.63 \mu \mathrm{cal} / \mathrm{cm}^{2} \mathrm{sec}$ is considered highly reliable.

The two successful heat flow measurements on Leg 22 were both taken on the Ninetyeast Ridge. They do not differ significantly from the mean of nine heat flow measurements $\left(1.55 \pm 0.41 \mu \mathrm{cal} / \mathrm{cm}^{2} \mathrm{sec}\right)$ taken by conventional oceanic techniques on the ridge. Thus, they present strong evidence that the surface measurements are reliable and that the Ninetyeast Ridge is cold and, hence, has probably been inactive during the past 5 to 10 m.y.

The excellent temperature measurements at Site 217 show that it is possible to measure downhole temperatures to better than $0.1^{\circ} \mathrm{C}$. With such a reliability and many downhole measurements to depths of 500 meters, it may be practicable to investigate the possible existence of major (1 to $10^{\circ} \mathrm{C}$ ) temperature changes in the bottom water of the oceans during the past 200,000 years. 
TABLE 3

Thermal Conductivity, Site 213

\begin{tabular}{|c|c|c|c|c|c|}
\hline $\begin{array}{l}\text { Core- } \\
\text { Section- } \\
\text { Interval }\end{array}$ & $\begin{array}{l}\text { Subbottom } \\
\text { Depth (m) }\end{array}$ & $\begin{array}{c}K \\
(\mathrm{mcal} / \mathrm{cm} \\
\left.\sec ^{\circ} \mathrm{C}\right)\end{array}$ & $\begin{array}{c}K_{\text {Corr }} \\
(\mathrm{mcal} / \mathrm{cm} \\
\left.\sec ^{\circ} \mathrm{C}\right)\end{array}$ & $\begin{array}{c}K \\
\text { (cm sec } \\
\text { mcal) }\end{array}$ & Comment \\
\hline $1-1,140$ & 2 & 1.539 & 1.510 & 0.6622 & \\
\hline $1-2,130$ & 4 & 1.590 & 1.559 & 0.6414 & \\
\hline $1-3,130$ & 5 & 1.513 & 1.484 & 0.6738 & \\
\hline $1-4,10$ & 6 & 1.426 & 1.400 & 0.7142 & \\
\hline $1-5,131$ & 8 & 1.517 & 1.491 & 0.6706 & \\
\hline $2-1.132$ & 10 & 1.848 & 1.820 & 0.5494 & $\begin{array}{l}\text { Gas, probe may be } \\
\text { in air cavity }\end{array}$ \\
\hline $2-2,130$ & 12 & 1.729 & 1.702 & 0.5875 & Gassey \\
\hline $\begin{array}{r}2-3,135 \\
2-4,95\end{array}$ & $\begin{array}{l}13 \\
14\end{array}$ & $\begin{array}{l}1.855 \\
1.719\end{array}$ & $\begin{array}{l}1.824 \\
1.692\end{array}$ & $\begin{array}{l}0.5482 \\
0.5910\end{array}$ & $\begin{array}{l}\text { Gassey } \\
\text { Gassey }\end{array}$ \\
\hline $2-5,140$ & 16 & 1.821 & 1.792 & 0.5580 & Gassey \\
\hline $2-6,130$ & 18 & 1.715 & 1.688 & 0.5924 & Gassey \\
\hline $3-1,135$ & 20 & 2.944 & 2.902 & 0.3445 & Looks very disturbed \\
\hline $3-3, \quad 15$ & 22 & 2.701 & 2.663 & 0.3755 & Looks very disturbed \\
\hline 34,135 & 24 & 2.416 & 2.380 & 0.4201 & Looks very disturbed \\
\hline $3-5,135$ & 26 & 3.010 & 2.967 & 0.3370 & Looks very disturbed \\
\hline $\begin{array}{r}3-6,120 \\
10-6, \quad 20\end{array}$ & $\begin{array}{l}27 \\
90\end{array}$ & $\begin{array}{l}1.717 \\
1.443\end{array}$ & $\begin{array}{l}1.694 \\
1.415\end{array}$ & $\begin{array}{l}0.5903 \\
0.7067\end{array}$ & Looks very disturbed \\
\hline
\end{tabular}

Note: Mean thermal conductivity corrected for environmental conditions $=1.910 \pm 0.500$ $\mathrm{mcal} / \mathrm{cm} \mathrm{sec}{ }^{\circ} \mathrm{C}$. Mean thermal resistivity corrected for environmental conditions = $0.5536 \pm 0.1170 \mathrm{~cm} \mathrm{sec}{ }^{\circ} \mathrm{C} / \mathrm{mcal}$.

\section{ACKNOWLEDGMENTS}

This work could not have been accomplished without the outstanding work of Alan Porter and Paul Porter on the downhole instrument and of Lamar Hayes, the operations manager, and Ted Gustafson, on the mechanics of the drilling operation. We are also grateful to Cotton Guess and the drilling crew for their advice, patience while we experimented, and superb cooperation on the drilling floor.

\section{REFERENCES}

Burns, R. E., 1970. Heat flow operations at Holes 35.0 and 35.1. In McManus, D. A., Burns, R. E., et al., Initial Reports of the Deep Sea Drilling Project, Volume V: Washington (U.S. Government Printing Office), p. 551-554.

Erickson, A., 1973. Initial report on downhole temperature and shipboard thermal conductivity measurements on Leg 19 of the D.S.D.P. In Creager, J. S., Scholl, D. W., et al., Initial Reports of the Deep Sea Drilling Project, Volume XIX: Washington (U.S. Government Printing Office).
Langseth, M. G., 1965. Techniques of measuring heat flow through the ocean floor. In Terrestrial heat flow, Lee, W. H. K. (Ed): Am. Geophys. Union Monogr., No. 8, p. 58.

Lee, W. H. K. and Uyeda, S., 1965. Review of heat flow data. In Terrestrial Heat Flow, Lee, W. H. K. (Ed): Am. Geophys. Union, Monogr. No. 8, p. 87-190.

Ratcliffe, E. H., 1960. The thermal conductivities of ocean sediments: Geophys. Res., v. 65, p. 1535-1541.

Vacquier, V. and Taylor, P. T., 1966. Geothermal and magnetic survey off the coast of Sumatra, 1-Presentation of data: Earthquake Res. Inst. Bull., v. 44, p. 531-541.

von Herzen, R. P., in preparation. Geothermal measurements on Leg 21. In Burns, R. E., Andrews, J. E., et al. Initial Reports of the Deep Sea Drilling Project, Volume XXI.

von Herzen, R. P. and Maxwell, A. E., 1959. The measurement of thermal conductivity of deep-sea sediments by a needle-probe method: J. Geophys. Res., v. 64 , p. $1557-1563$.

von Herzen, R. P., Fiske, R. J., and Sutton, G., 1971. Geothermal measurements on Leg 8. In Tracey, J. T., Sutton, G. H. et al., Initial Reports of the Deep Sea Drilling Project, Volume VIII. Washington (U.S. Government Printing Office), 837. 
TABLE 4

Thermal Conductivity, Site 214

\begin{tabular}{|c|c|c|c|c|c|}
\hline $\begin{array}{l}\text { Core } \\
\text { Section- } \\
\text { Interval }\end{array}$ & $\begin{array}{l}\text { Subbottom } \\
\text { Depth (m) }\end{array}$ & $\begin{array}{c}K \\
(\mathrm{mcal} / \mathrm{cm} \\
\left.\sec ^{\circ} \mathrm{C}\right)\end{array}$ & $\begin{array}{c}K_{\mathrm{Corr}} \\
(\mathrm{mcal} / \mathrm{cm} \\
\left.\sec ^{\circ} \mathrm{C}\right)\end{array}$ & $\begin{array}{c}K \\
\left(\mathrm{~cm} \mathrm{sec}^{\circ} \mathrm{C} /\right. \\
\text { mcal) }\end{array}$ & Comment \\
\hline $13-4,30$ & 119 & 2703 & 2.634 & 0.3796 & White ooze, sides watery \\
\hline $13-4,130$ & 120 & 2.696 & 2.634 & 0.3796 & White ooze, sides watery \\
\hline $14-4,30$ & 128 & 2.510 & 2.451 & 0.4080 & White ooze, sides watery \\
\hline $14-4,130$ & 129 & 2.638 & 2.580 & 0.3876 & White ooze, sides watery \\
\hline $15-4,30$ & 138 & 2.603 & 2.547 & 0.3926 & \\
\hline $16-4,130$ & 149 & 2.563 & 2.511 & 0.3982 & White ooze, watery \\
\hline $17-4,130$ & 158 & 2.741 & 2.691 & 0.3716 & White ooze \\
\hline $18-4,30$ & 167 & 2.679 & 2.637 & 0.3792 & \\
\hline $18-4,130$ & 168 & 2.883 & 2.837 & 0.3524 & \\
\hline $19-4,30$ & 176 & 2.862 & 2.822 & 0.3543 & \\
\hline $19-4,130$ & 177 & 2.825 & 2.780 & 0.3597 & \\
\hline $20-4,130$ & 187 & 2.922 & 2.883 & 0.3468 & \\
\hline $21-4, \quad 30$ & 195 & 3.021 & 2.992 & 0.3342 & Firm white ooze \\
\hline $21-4,130$ & 196 & 3.038 & 3.004 & 0.3328 & \\
\hline $22-4, \quad 30$ & 205 & 2.919 & 2.895 & 0.3454 & White ooze \\
\hline $22-4,130$ & 206 & 3.032 & 3.004 & 0.3328 & White ooze \\
\hline $23-4, \quad 30$ & 214 & 3.177 & 3.154 & 0.3170 & White ooze \\
\hline $23-4,130$ & 215 & 3.373 & 3.343 & 0.2991 & \\
\hline $24-4, \quad 30$ & 224 & 3.985 & 3.958 & 0.2526 & \\
\hline $24-4,130$ & 225 & 3.323 & 3.297 & 0.3033 & \\
\hline $26-4,20$ & 243 & 3.334 & 3.314 & 0.3017 & $\begin{array}{l}\text { Almost soupy, much } \\
\text { side water }\end{array}$ \\
\hline $26-4,130$ & 244 & 3.278 & 3.259 & 0.3068 & $\begin{array}{l}\text { Almost soupy, much } \\
\text { side water }\end{array}$ \\
\hline $27-4,130$ & 253 & 3.593 & 3.571 & 0.2800 & Soupy white ooze \\
\hline $28-4, \quad 30$ & 262 & 3.204 & 3.197 & 0.3127 & \\
\hline $28-4,130$ & 263 & 3.202 & 3.192 & 0.3132 & \\
\hline $29-4,30$ & 271 & 3.174 & 3.169 & 0.3155 & \\
\hline $29-4,130$ & 272 & 4.228 & 4.221 & 0.2369 & \\
\hline
\end{tabular}

Note: Mean thermal conductivity corrected for environmental conditions $=3.015 \pm 0.427$ $\mathrm{mcal} / \mathrm{cm} \mathrm{sec}{ }^{\circ} \mathrm{C}$. Mean thermal resistivity corrected for environmental conditions = $0.3378 \pm 0.0434 \mathrm{~cm} \mathrm{sec}^{\circ} \mathrm{C} / \mathrm{mcal}$. 
TABLE 5

Thermal Conductivity, Site 216

\begin{tabular}{lccccl}
\hline $\begin{array}{l}\text { Core } \\
\text { Section- } \\
\text { Interval }\end{array}$ & $\begin{array}{c}\text { Subbottom } \\
\text { Depth }(\mathrm{m})\end{array}$ & $\begin{array}{c}K \\
(\mathrm{mcal} / \mathrm{cm} \\
\left.\mathrm{sec}^{\circ} \mathrm{C}\right)\end{array}$ & $\begin{array}{c}K_{\mathrm{Corr}} \\
\left(\mathrm{mcal}^{\circ} \mathrm{cm}\right)\end{array}$ & $\begin{array}{c}K \\
\mathrm{sec}^{\circ} \mathrm{cm} \mathrm{sec} \\
\mathrm{mcal}^{\circ} \mathrm{C} /\end{array}$ & Comment \\
\hline 2-4, 30 & 49 & 2.451 & 2.368 & 0.4223 & Chalk \\
$2-4,130$ & 50 & 2.462 & 2.376 & 0.4209 & Chalk \\
4-4, 30 & 125 & 2.773 & 2.695 & 0.3711 & Chalk \\
$4-4,130$ & 126 & 2.774 & 2.693 & 0.3713 & Chalk \\
$5-4,130$ & 164 & 2.700 & 2.628 & 0.3805 & Chalk \\
$6-4,40$ & 173 & 2.864 & 2.795 & 0.3578 & \\
$6-4,130$ & 174 & 3.164 & 3.087 & 0.3239 & \\
$7-2,30$ & 179 & 2.910 & 2.838 & 0.3524 & \\
$7-2,130$ & 180 & 2.881 & 2.809 & 0.3560 & \\
$9-3,100$ & 201 & 2.941 & 2.873 & 0.3481 & Disturbed \\
$10-2,30$ & 208 & 2.756 & 2.694 & 0.3712 & \\
$10-2,120$ & 209 & 2.792 & 2.731 & 0.3662 & \\
$11-1,120$ & 217 & 2.841 & 2.778 & 0.3599 & \\
$12-1,95$ & 223 & 3.552 & 3.479 & 0.2874 & \\
$14-2,12$ & 246 & 3.151 & 3.087 & 0.3239 & \\
$15-2,94$ & 256 & 3.172 & 3.113 & 0.3212 & \\
& & & & &
\end{tabular}

Note: Mean thermal conductivity corrected for environmental conditions $=2.795 \pm 0.267$ $\mathrm{mcal} / \mathrm{cm} \mathrm{sec}{ }^{\circ} \mathrm{C}$. Mean thermal resistivity corrected for environmental conditions = $0.3609 \pm 0.332 \mathrm{~cm} \mathrm{sec}^{\circ} \mathrm{C} / \mathrm{mcal}$.

TABLE 6

Thermal Conductivity, Site 217

\begin{tabular}{lccccl}
\hline $\begin{array}{c}\text { Core } \\
\begin{array}{c}\text { Section } \\
\text { Interval }\end{array}\end{array}$ & $\begin{array}{c}\text { Subbottom } \\
\text { Depth }(\mathrm{m})\end{array}$ & $\begin{array}{c}K \\
(\mathrm{mcal} / \mathrm{cm} \\
\left.\mathrm{sec}^{\circ} \mathrm{C}\right)\end{array}$ & $\begin{array}{c}K_{\text {Corr }} \\
\left(\mathrm{mcal}^{\circ} \mathrm{cm}\right. \\
\left.\mathrm{sec}^{\circ} \mathrm{C}\right)\end{array}$ & $\begin{array}{c}K \\
\left(\mathrm{~cm} \mathrm{sec}^{\circ} \mathrm{C} /\right.\end{array}$ & \multicolumn{1}{c}{ Comment } \\
\hline $1-2,46$ & 2 & 2.032 & 1.962 & 0.5096 & Soft Gray Mud \\
$1-2,130$ & 3 & 2.116 & 2.042 & 0.4897 & Soft Gray Mud \\
$1-4,30$ & 5 & 2.216 & 2.140 & 0.4672 & Soft Gray Mud \\
$1-4,130$ & 6 & 2.390 & 2.308 & 0.4332 & Soft Gray Mud \\
$2-2,30$ & 11 & 2.577 & 2.494 & 0.4009 & Soft Gray Mud \\
$2-2,130$ & 12 & 2.528 & 2.442 & 0.4095 & Soft Gray Mud \\
$2-5,30$ & 16 & 2.399 & 2.322 & 0.4306 & Soft Gray Mud \\
$2-5,130$ & 17 & 2.441 & 2.363 & 0.4231 & Soft Gray Mud \\
$3-2,30$ & 21 & 2.316 & 2.241 & 0.4462 & Soft Gray Mud \\
$3-2,130$ & 22 & 2.425 & 2.347 & 0.4260 & Soft Gray Mud \\
$3-4,30$ & 24 & 2.454 & 2.379 & 0.4203 & Soft Gray Mud \\
$3-4,130$ & 25 & 2.280 & 2.207 & 0.4531 & Soft Gray Mud \\
$4-2,30$ & 29 & 2.518 & 2.442 & 0.4095 & Gas Bubbles in Section \\
$4-2,130$ & 30 & 2.645 & 2.565 & 0.3898 & Gas Bubbles in Section \\
$4-4,90$ & 33 & 2.467 & 2.393 & 0.4178 & Gas Bubbles in Section \\
$3-2,50$ & 72 & 2.504 & 2.445 & 0.4090 & Chalk (Gray) \\
$3-2,130$ & 73 & 2.375 & 2.320 & 0.4310 & Chalk (Gray) \\
$4-4,60$ & 121 & 2.354 & 2.322 & 0.4306 & Chalk (Gray) \\
$4-4,115$ & 122 & 2.683 & 2.648 & 0.3776 & \\
$6-4,130$ & 188 & 2.939 & 2.939 & 0.3402 & \\
\hline & & & & & \\
\hline
\end{tabular}

Note: Mean thermal conductivity corrected for environmental conditions $=2.336 \pm 0.163$ $\mathrm{mcal} / \mathrm{cm} \mathrm{sec}{ }^{\circ} \mathrm{C}$. Mean thermal resistivity corrected for environmental conditions = $0.4303 \pm 0.0315 \mathrm{~cm} \mathrm{sec}{ }^{\circ} \mathrm{C} / \mathrm{mcal}$. 


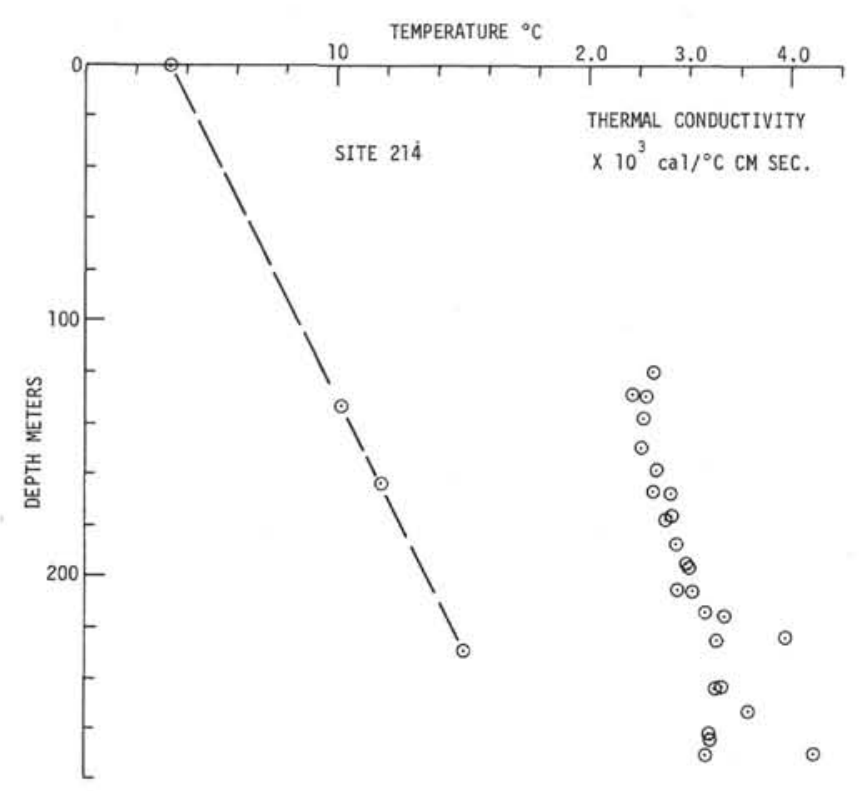

Figure 6. Equilibrium temperatures and thermal conductivities plotted versus depth for Site 214.

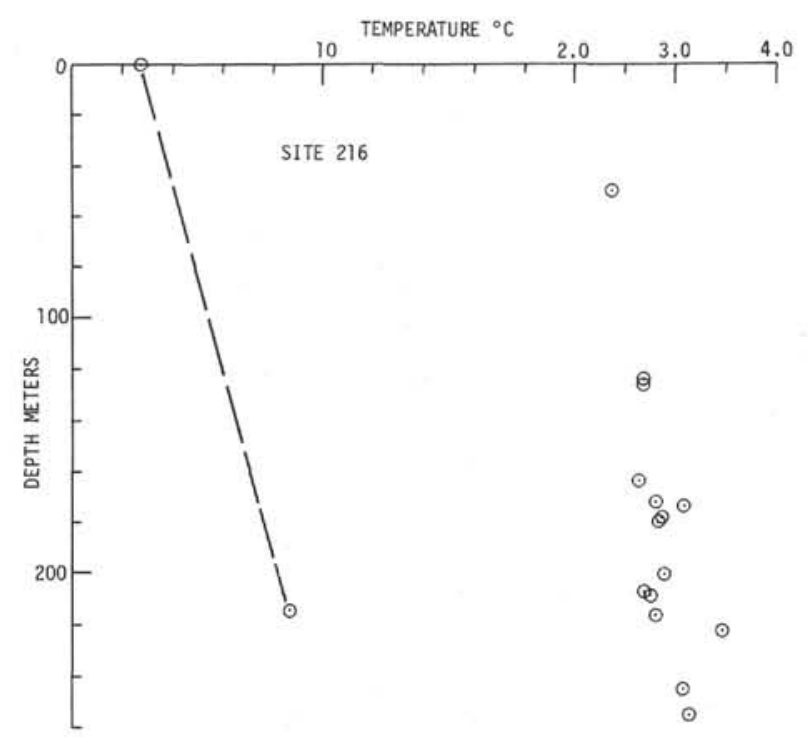

Figure 7. Equilibrium temperatures and thermal conductivities plotted versus depth for Site 216.

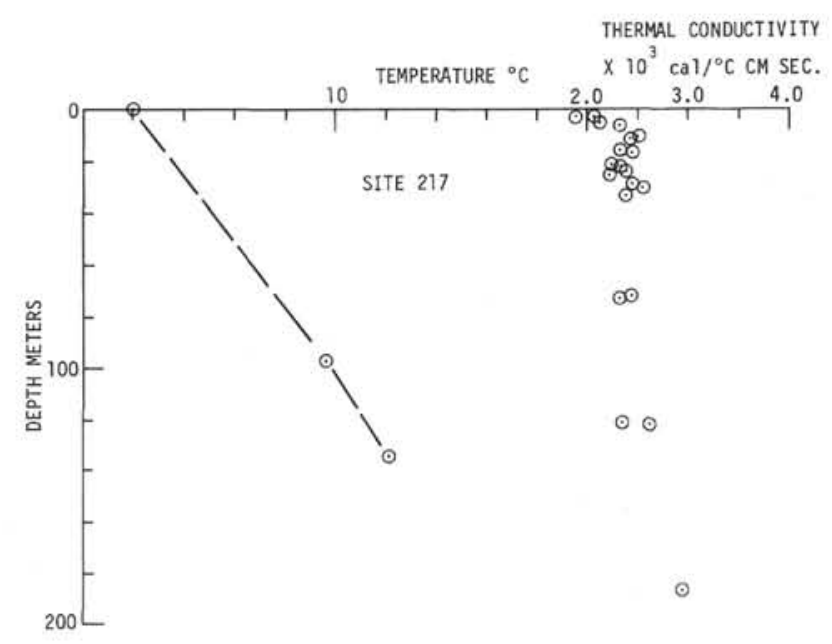

Figure 8. Equilibrium temperatures and thermal conductivities plotted versus depth for Site 217. 